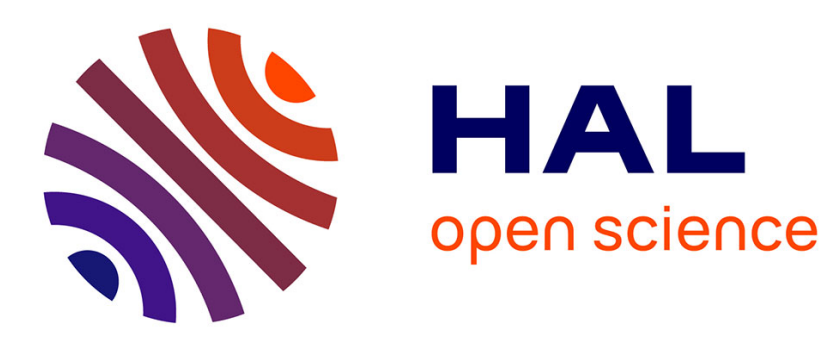

\title{
Perforin level in CD4 T cells from patients with systemic lupus erythematosus
}

Anna Kozlowska, Pawel Hrycaj, Jan K. Łącki, Pawel Piotr Jagodziński

\section{To cite this version:}

Anna Kozlowska, Pawel Hrycaj, Jan K. Łącki, Pawel Piotr Jagodziński. Perforin level in CD4 T cells from patients with systemic lupus erythematosus. Rheumatology International, 2010, 30 (12), pp.1627-1633. 10.1007/s00296-009-1329-1 . hal-00568323

\section{HAL Id: hal-00568323 \\ https://hal.science/hal-00568323}

Submitted on 23 Feb 2011

HAL is a multi-disciplinary open access archive for the deposit and dissemination of scientific research documents, whether they are published or not. The documents may come from teaching and research institutions in France or abroad, or from public or private research centers.
L'archive ouverte pluridisciplinaire $\mathbf{H A L}$, est destinée au dépôt et à la diffusion de documents scientifiques de niveau recherche, publiés ou non, émanant des établissements d'enseignement et de recherche français ou étrangers, des laboratoires publics ou privés. 


\section{Perforin level in $\mathrm{CD4}^{+} \mathrm{T}$ cells from patients with systemic lupus erythematosus}

Anna Kozłowska ${ }^{1}$, Paweł Hrycaj ${ }^{2}$, Jan K. Lącki $^{3}$, Paweł P. Jagodziński ${ }^{1}$

${ }^{1}$ Department of Biochemistry and Molecular Biology, ${ }^{2}$ Department of Rheumatology and Clinical Immunology Poznań University of Medical Sciences, Poznań, Poland

${ }^{3}$ Institute of Rheumatology, Warsaw Poland

Running heading: perforin expression in $\mathrm{CD}^{+} \mathrm{T}$ cells

${ }^{*}$ Corresponding author: Dr Paweł P. Jagodziński, Department of Biochemistry and Molecular Biology, University of Medical Sciences, 6 Święcickiego St., 60-781 Poznań, Poland Tel: (48 61) 85465 13, Fax: (48 61) 85465 10, E-mail: pjagodzi@am.poznan.pl 


\section{Summary}

$\mathrm{CD}^{+} \mathrm{T}$ cells from patients with systemic lupus erythematosus (SLE) exhibit increased expression of various proteins contributing to defective function of $\mathrm{CD} 4^{+} \mathrm{T}$ cells.

We evaluated the transcript and protein levels of perforin (PRF1) in $\mathrm{CD} 4^{+} \mathrm{T}$ cells from SLE patients $(n=41)$ and healthy individuals $(n=34)$. The $C D 4^{+} T$ cells were obtained by a positive biomagnetic separation system. The amounts of mRNA were determined by reverse transcription and real-time quantitative PCR. The protein levels in the $\mathrm{CD}^{+} \mathrm{T}$ cells were evaluated by western blotting analysis. We observed significantly higher levels of PRF1 protein $(\mathrm{p}=0.013)$ in SLE CD4 ${ }^{+} \mathrm{T}$ cells than in controls. There was no significant increase in PRF1 transcript levels $(\mathrm{p}=0.908)$ in $\mathrm{CD}^{+} \mathrm{T}$ cells from SLE patients as compared to healthy individuals. Moreover, we did not observe a correlation between PRF1 transcript and protein levels in SLE CD4 ${ }^{+} \mathrm{T}$ cells and disease activity expressed by the SLEDAI scale.

We confirmed previous observations that demonstrated higher levels of PRF1 protein in $\mathrm{CD}^{+} \mathrm{T}$ cells from SLE patients. However, we did not find a correlation between PRF1 transcripts and proteins in $\mathrm{CD} 4^{+} \mathrm{T}$ cells and SLE disease activity. 


\section{Introduction}

Systemic lupus erythematosus (SLE) is a progressive, systemic autoimmune disease with multi-organ engagement, characterized by an immune response directed against self antigens [1]. The SLE target tissues include skin, kidneys, joints, and the central nervous system [1]. Exposure to certain chemicals, drugs, food, and infectious factors also contributes to SLE incidence [2,3]. Moreover, there is an evident genetic background in the incidence of this autoimmune disorder [4-6].

Three major processes are considered in the initiation, development and clinical manifestation of SLE; they include an increase in the plasma concentration of nuclear autoantigens, T cell-dependent stimulation of B cells for the biosynthesis of antinuclear antibodies $(\mathrm{Ab})$, and organ damage mediated by anti-double stranded DNA Ab and immune complexes [7-9].

Increased apoptosis and reduced removal of apoptotic cells lead to the formation of necrotic cells, which are source of nuclear antigens for biosynthesis of $\mathrm{Ab}[10,11]$. Cytotoxic T lymphocytes involved in killing other host cells may be significant producers of preferential and selective autoantigens [12]. T cells from lupus patients may kill autologous monocytes/macrophages, and may thus contribute to both increase of the amount of antigenic apoptotic material and the reduction of its clearance [13, 14].

It has been concluded that defective helper functions of $\mathrm{CD} 4^{+} \mathrm{T}$ cells can contribute to improper activation of B cells and autoantibody production [15-18]. Despite CD4 ${ }^{+} \mathrm{T}$ cells function mainly as helper cells, a, subpopulation of these cells also functions in an effector capacity by carrying out cytotoxicity in a peptide-specific and MHC class II-restricted mode [19]. The latter function of $\mathrm{CD}^{+}{ }^{\mathrm{T}}$ cells mainly depends on granzyme $\mathrm{B}$ and perforin-1 (PRF1) exocytosis rather than on CD95-ligand binding to CD95 [19]. An increased presence of cytotoxic $\mathrm{CD} 4^{+} \mathrm{T}$ cells has been associated with vascular damage and incidence of various 
autoimmune diseases, including SLE [20-24]. The overexpression of PRF1 in both CD4 ${ }^{+} \mathrm{T}$ and $\mathrm{CD}^{+} \mathrm{T}$ cells from peripheral mononuclear cells (PBMC), and its role in SLE pathogenesis has been demonstrated [24, 25]. Kaplan et al. (2004), employing staining of PBMC and flow cytometry analysis, showed a significant correlation between percentage of $\mathrm{PRF}^{+} \mathrm{CD}^{+} \mathrm{T}$ cells in PBMC and disease activity in SLE patients [24].

We decided to examine mRNA and protein levels in whole $\mathrm{CD}^{+} \mathrm{T}$ cells from a larger group of SLE patients $(n=41)$ and healthy individuals $(n=34)$ than those demonstrated by Kaplan et a. [24]. Whole $\mathrm{CD}^{+} \mathrm{T}$ cells from whole peripheral blood were isolated by positive biomagnetic separation. Isolated mRNA and proteins from $\mathrm{CD}^{+}{ }^{+} \mathrm{T}$ cells were used for reverse transcription, real-time quantitative PCR and western blotting analysis. Subsequently we determined whether there exist correlations between increased PRF1 transcript and protein levels in $\mathrm{CD}^{+} \mathrm{T}$ cells and SLE disease activity.

\section{Materials and methods}

\section{Patients and controls}

Forty-one consecutive SLE patients seen between September 2006 and October 2008 at the Institute of Rheumatology in Warsaw and Department of Rheumatology and Clinical Immunology at the Poznań University of Medical Sciences, Poland were included in the present study (Table 1). Patients fulfilled at least 4 of the American College of Rheumatology 1982 revised criteria for SLE [26, 27]. Disease activity for the SLE patients was assessed using the SLEDAI scale (Table 1) [28]. Twenty-four patients were treated by prednisone. Seventeen patients were receiving methyloprednisone, and ten patients were also receiving hydroxychloroquine. In order to reduce the effect of corticosteroid medication on our results, patients who were on prednisone or methyloprednisone were asked not to take this medication for at least $24 \mathrm{~h}$ before drawing blood. Clinical manifestations of SLE in the patient group 
included central nervous system (22\%), vascular (20\%), renal (42\%), musculoskeletal (29\%), serosal (20\%), dermal (34\%), immunologic (85\%), febrile (8\%), and hematologic (29\%) components.

Both patients and control groups were of Polish Caucasian origin. The control group included thirty-four healthy individuals (32 women and 2 men). The mean age of healthy individuals was $36.6 \pm 9.6$ years. The protocol of the investigation was approved by the Local Ethical Committee of Poznań University of Medical Sciences. Written informed consent was signed by all participating individuals.

\section{Antibodies}

Rabbit polyclonal anti- PRF1 Ab (H-315), goat anti-rabbit horseradish peroxidase (HRP)-conjugated Ab and anti-actin HRP-conjugated Ab (clone I-19) were provided by Santa Cruz Biotechnology (Santa Cruz, CA).

\section{$\mathrm{CD4}^{+} \mathrm{T}$ cell isolation}

The $\mathrm{CD}^{+}$cells were isolated from a $10 \mathrm{ml}$ whole peripheral blood sample taken from each patient, employing the positive biomagnetic separation technique using DETACHaBEADs

${ }^{\circledR}$ M-450 CD4 from Dynal Biotech (Lake Success, NY) (29). The flow cytometry analysis $(\mathrm{n}=29)$ indicated $95.6 \% \pm 1.4$ purity of $\mathrm{CD} 4^{+} \mathrm{T}$ cells.

\section{Real-time quantitative PCR (RQ-PCR) analysis of PRF1transcript levels in $\mathrm{CD4}^{+} \mathrm{T}$ cells}

Total RNA was isolated according to the method of Chomczyński and Sacchi [29]. RNA samples were treated with DNase I, and $1 \mu \mathrm{g}$ RNA was reverse-transcribed into cDNA using oligo-dT primers. RQ-PCR was conducted in a Light Cycler real-time PCR detection system from Roche Diagnostics GmbH, (Mannheim, Germany) using SYBR ${ }^{\circledR}$ Green I as detection dye. Target cDNA was quantified using relative quantification method with a calibrator. The calibrator was prepared as a cDNA mix from all SLE and control samples and 
consecutive dilutions were used to create a standard curve as described in Relative

Quantification Manual Roche Diagnostics GmbH, (Mannheim, Germany). For amplification, $2 \mu \mathrm{l}$ of cDNA solution was added to $18 \mu \mathrm{l}$ of QuantiTect ${ }^{\circledR}$ SYBER $^{\circledR}$ Green PCR Master Mix QIAGEN GmbH (Hilden, Germany) and primers. The quantity of PRF1 transcript in each sample was standardized by human mitochondrial ribosomal protein L19 (hMRPL19).

The PRF! cDNA 170 bp amplicon was amplified employing the pair of primers: 5'CACCCTCTGTGAAAATGCCCTAC3' (forward) and 5’TCCAGTCGTTGCGGATGCTAC3' (reverse).

The hMRPL19 cDNA 171bp amplicon was amplified using primers:

5'ACTTTATAATCCTCGGGTC 3' (forward) and 5'ACTTTCAGCTCATTAACAG 3' (reverse). These PRF1 and hMRPL19 primers were designed based on sequences ENST00000373209 and ENST00000393909 respectively, located in Ensembl Genome Browser (www.ensembl.org). The PRF1mRNA levels were expressed as multiples of these cDNA concentrations in the calibrator.

\section{Western blot analysis of PRF1protein contents in $\mathrm{CD4}^{+} \mathrm{T}$ cells.}

$\mathrm{CD} 4^{+}$lymphocytes were lysed in lysis buffer, and ten micrograms of protein was resuspended in sample buffer. The proteins were separated on $10 \%$ Tris-glycine gel using sodium dodecyl sulfate-polyacrylamide gel electrophoresis (SDS-PAGE) and transferred to PVDF membrane. Immunodetection was performed with rabbit polyclonal anti-PRF1, and HRP-conjugated goat anti-rabbit Ab. The membranes were reblotted with anti-actin HRPconjugated $\mathrm{Ab}$ to equalize protein loading of the lanes. To detect the examined protein from the same blot membrane we used stripping buffer. Bands were revealed using SuperSignal West Femto Maximum Sensitivity Substrate Pierce (Rockford, IL). The quantities of western blot-detected PRF1and $\beta$-actin proteins were determined based on the band optical density. 
The band densitometry readings were normalized to $\beta$-actin loading control to calculate the PRF1-to $\beta$-actin optical density ratio.

\section{Statistical analysis}

Statistical analysis was conducted using StatSoft, Inc. (2001). STATISTICA (data analysis software system), version 6. www.statsoft.com. The significance of differences between groups was determined using nonparametric Mann-Whitney test. Correlations between PRF1 expression and disease activity as defined by the SLEDAI scale were assessed by Spearman analysis.

\section{Results}

\section{PRF1 transcript and protein levels in $\mathrm{CD4}^{+} \mathrm{T}$ cells from SLE patients and controls}

To compare PRF1 transcript and protein levels in $\mathrm{CD}^{+}{ }^{+} \mathrm{T}$ cells from SLE patients and controls, we used RQ-PCR and western blotting analysis, respectively. There was no significant increase in PRF1 transcript level in SLE CD4 ${ }^{+} \mathrm{T}$ cells as compared to controls $(\mathrm{p}=0.908)$ (Figure 1A and Table 2). However, we observed significantly higher content of PRF1 protein in $\mathrm{CD}^{+} \mathrm{T}$ cells from SLE patients as compared to healthy individuals $(\mathrm{p}=$ 0.013) (Figures 1B, C, and Table 2). There was no correlation between PRF1 transcript and protein levels in SLE CD4 ${ }^{+} \mathrm{T}$ cells and disease activity defined by the SLEDAI scale (Figures 2A and 2B). We also did not find a relationship between patients' age, disease duration, drug treatment, and type of individual organ manifestation with PRF1 transcript and protein levels in SLE CD4 ${ }^{+} \mathrm{T}$ cells (data not shown). 


\section{Discussion}

It has previously been demonstrated that there is an increased expression many proteins responsible for defective function of $\mathrm{CD}^{+} \mathrm{T}$ cells $[15,16,18]$. These proteins include signal molecules, transcription factors, components of TCR/CD3 complex, costimulatory proteins, cytokines and molecules involved in the cytotoxic response $[15,16,18]$.

PRF1 protein, with molecular mass of 60 to $75 \mathrm{kD}$, is a pore-forming molecule presented in cytotoxic lymphocytes, which execute immune mediated cell lysis [30]. The $P R F 1$ gene is expressed primarily in NK cells and effector $\mathrm{CD}^{+} \mathrm{T}$ cells $[31,32] . P R F 1$ is also expressed in a subpopulation of cytotoxic $\mathrm{CD} 4^{+} \mathrm{T}$ cells, which may combat various pathogens (33-39). An increased number of cytotoxic $\mathrm{CD}^{+} \mathrm{T}$ cells has been observed in patients with multiple sclerosis, rheumatoid arthritis, inflammatory bowel disease, and acute coronary syndromes [20-23].

Lu et al (2003) demonstrated that DNA methylation and chromatin structure regulate PRF1 expression in T cells [40]. Moreover, Kaplan et al. (2004) showed that DNA methylation inhibitors increased $P R F 1$ expression in $\mathrm{CD}^{+} \mathrm{T}$ cells. This increase in $P R F 1$ transcription in $\mathrm{CD}^{+} \mathrm{T}$ cells was due to demethylation of a DNA region, which is hypomethylated in primary $\mathrm{CD}^{+} \mathrm{T}$ cells expressing PRF1 [24]. Kaplan et al. (2004) also indicated that increased PRF1 transcription in $\mathrm{CD}^{+} \mathrm{T}$ cells from SLE patients was related to demethylation of this DNA region [24]. Recently, Luo et al. (2009) disclosed that DNA demethylation at the $P R F 1$ locus is responsible for $P R F 1$ overexpression in $\mathrm{CD}^{+} \mathrm{T}$ cells from patients with subacute cutaneous lupus erythematosus [41].

We observed significantly higher levels of PRF1 protein in SLE CD4 ${ }^{+} \mathrm{T}$ cells than in healthy individuals. Our findings are consistent with Kaplan et al. (2004), who demonstrated a significant increase in PRF1 protein levels in SLE patients [24]. They also indicated that 
aberrant PRF1 protein levels in SLE $\mathrm{CD}^{+}{ }^{+} \mathrm{T}$ cells may contribute to killing of autologous monocytes [24].

We also found higher PRF1 transcript levels in SLE CD4 ${ }^{+} \mathrm{T}$ cells than in controls, but this difference was not statistically significant and did not correlate with disease activity. Although PRF1 protein level was higher in SLE CD4 ${ }^{+} \mathrm{T}$ cells than in controls, it also did not correlate with disease activity. Our findings suggest that an increased PRF1 protein content in SLE CD4 ${ }^{+} \mathrm{T}$ cells does not perpetuate disease activity in our investigated group.

Kaplan et al. (2004) observed that $\mathrm{CD}^{+} \mathrm{T}$ cells from patients with active, but not inactive, lupus exhibited increased PRF1 transcript levels in CD4 ${ }^{+} \mathrm{T}$ cells [24]. Using flow cytometry analysis, they also demonstrated that the increase in PRF1 protein contents in SLE $\mathrm{CD}^{+} \mathrm{T}$ cells was correlated to disease activity expressed by the SLEDAI scale [29]. These discrepancies between our observations and those of Kaplan et al. may result from the application of different methods in the determination of PRF1 protein levels in $\mathrm{CD}^{+}{ }^{+}$cells to establish correlation with disease activity.

The cytotoxic/effector $\mathrm{CD} 4^{+} \mathrm{T}$ cells make up a small amount of the whole circulating $\mathrm{CD} 4^{+} \mathrm{T}$ population [42]. These cells constitute the subset of $\mathrm{CD} 45 \mathrm{R} 0^{+} \mathrm{CD} 27^{-}$activated $\mathrm{CD} 4^{+}$ $\mathrm{T}$ cells, which are formed during differentiation of naive CD45RA ${ }^{+} \mathrm{CCR} 7^{+} \mathrm{T}$ cells $[42,43]$. Therefore, our analysis, conducted on the whole $\mathrm{CD} 4^{+} \mathrm{T}$ cell population after immune magnetic enrichment, may underestimate PRF1 transcript and protein levels in cytotoxic/effector $\mathrm{CD} 4^{+} \mathrm{T}$ cells. This may be responsible for the discrepancies observed between our results and those of Kaplan et al. [24]. These differences can also be due to varied genetics factors associated with the distinct racial structure of the examined groups or/and an exposure to disparate environmental factors contributing to SLE in these populations $[3,4]$. 
Our study confirmed previous observations that demonstrated increased PRF1 protein contents in $\mathrm{CD}^{+} \mathrm{T}$ cells from SLE patients. However, we did not find a correlation between PRF1 protein and transcript levels in $\mathrm{CD}^{+} \mathrm{T}$ cells and SLE disease activity. Therefore our results require verification in groups of SLE patients in other cohorts.

\section{Acknowledgements}

Supported by grant No. N N402 242433 from Polish Ministry of Scientific Research and Information Technology. We would like to acknowledge Dr. Margarita Lianeri for her assistance. 


\section{References}

1. Ruiz-Irastorza G, Khamashta MA, Castellino G, Hughes GR (2001) Systemic lupus erythematosus. Lancet 357:1027-1032.

2. Jönsen A, Bengtsson AA, Nived O, Truedsson L, Sturfelt G (2007) Gene-environment interactions in the aetiology of systemic lupus erythematosus. Autoimmunity 40: 613617.

3. Love LA (1994) New environmental agents associated with lupus-like disorders. Lupus 3:467-471

4. Wong M, Tsao BP (2006) Current topics in human SLE genetics. Springer Semin Immunopathol .: 28: 97-107.

5. Hom G, Graham RR, Modrek B, Taylor KE, Ortmann W, Garnier S, Lee AT, Chung SA, Ferreira RC, Pant PV, Ballinger DG, Kosoy R, Demirci FY, Kamboh MI, Kao AH, Tian C, Gunnarsson I, Bengtsson AA, Rantapää-Dahlqvist S, Petri M, Manzi S, Seldin MF, Rönnblom L, Syvänen AC, Criswell LA, Gregersen PK, Behrens TW (2008) Association of systemic lupus erythematosus with C8orf13-BLK and ITGAMITGAX. N Engl J Med 358: 900-909.

6. International Consortium for Systemic Lupus Erythematosus Genetics (SLEGEN), Harley JB, Alarcón-Riquelme ME, Criswell LA, Jacob CO, Kimberly RP, Moser KL, Tsao BP, Vyse TJ, Langefeld CD, Nath SK, Guthridge JM, Cobb BL, Mirel DB, Marion MC, Williams AH, Divers J, Wang W, Frank SG, Namjou B, Gabriel SB, Lee AT, Gregersen PK, Behrens TW, Taylor KE, Fernando M, Zidovetzki R, Gaffney PM, Edberg JC, Rioux JD, Ojwang JO, James JA, Merrill JT, Gilkeson GS, Seldin MF, Yin H, Baechler EC, Li QZ, Wakeland EK, Bruner GR, Kaufman KM, Kelly JA (2008) Genome-wide association scan in women with systemic lupus erythematosus identifies susceptibility variants in ITGAM, PXK, KIAA1542 and other loci. Nat Genet 40: 204-210

7. Quigg RJ (2004) Complement and autoimmune glomerular diseases. Curr Dir Autoimmun 7: 165-180

8. Pirner K, Rascu A, Nurnberg W, Rubbert A, Kalden JR, Manger B. (1994) Evidence for direct anti-heparin-sulphate reactivity in sera of SLE patients. Rheumatol Int 14: $169-174$

9. Nakajima M, Nakajima A, Kayagaki N, Honda M, Yagita H, Okumura K. (1997) Expression of Fas ligand and its receptor in cutaneous lupus: implication in tissue injury. Clin Immunol Immunopathol. 83: 223-229

10. Utz PJ, Anderson P (1998) Posttranslational protein modifications, apoptosis, and the bypass of tolerance to autoantigens. Arthritis Rheum 41:1152-1160.

11. Rosen A, Casciola-Rosen L (1999) Autoantigens as substrates for apoptotic proteases: implications for the pathogenesis of systemic autoimmune disease. Cell Death Differ 6:6-12.

12. Casciola-Rosen L, Andrade F, Ulanet D, Wong WB, Rosen A (1999) Cleavage by granzyme B is strongly predictive of autoantigen status: implications for initiation of autoimmunity. J Exp Med 190:815-826. 
13. Richardson BC, Strahler JR, Pivirotto TS, Quddus J, Bayliss GE, Gross LA, O'Rourke KS, Powers D, Hanash SM, Johnson MA. (1992) Phenotypic and functional similarities between 5-azacytidine-treated $\mathrm{T}$ cells and a $\mathrm{T}$ cell subset in patients with active systemic lupus erythematosus. Arthritis Rheum. 35: 647-62

14. Kaplan MJ, Lewis EE, Shelden EA, Somers E, Pavlic R, McCune WJ, Richardson BC (2002) The apoptotic ligands TRAIL, TWEAK, and Fas ligand mediate monocyte death induced by autologous lupus T cells. J. Immunol. 169:6020-6029

15. Crispín JC, Tsokos GC (2008) Novel molecular targets in the treatment of systemic lupus erythematosus. Autoimmun Rev 7:256-261.

16. Krishnan S, Farber DL, Tsokos GC (2003) T cell rewiring in differentiation and disease. J Immunol 171:3325-3331.

17. Stohl W, Metyas S, Tan SM, Cheema GS, Oamar B, Xu D, Roschke V, Wu Y, Baker KP, Hilbert DM. (2003) B lymphocyte stimulator overexpression in patients with systemic lupus erythematosus: longitudinal observations. Arthritis Rheum 48:34753486.

18. Zhou Y, Lu Q (2008) DNA methylation in T cells from idiopathic lupus and druginduced lupus patients. Autoimmun Rev 7:376-383

19. Appay V, Zaunders JJ, Papagno L, Sutton J, Jaramillo A, Waters A, Easterbrook P, Grey P, Smith D, McMichael AJ, Cooper DA, Rowland-Jones SL, Kelleher AD (2002) Characterization of CD4(+) CTLs ex vivo. J Immunol 2002, 168:5954-5958.

20. Markovic-Plese S, Cortese I, Wandinger KP, McFarland HF, Martin R (2001) CD4+CD28S costimulation-independent T cells in multiple sclerosis. J Clin Invest 108:1185-1194.

21. Fasth AE, Snir O, Johansson AA, Nordmark B, Rahbar A, Af KE, Bjorkstrom NK, Ulfgren AK, van Vollenhoven RF, Malmstrom V, Trollmo C (2007) Skewed distribution of proinflammatory CD4+CD28null $\mathrm{T}$ cells in rheumatoid arthritis. Arthritis Res Ther 9:R87.

22. Kobayashi T, Okamoto S, Iwakami Y, Nakazawa A, Hisamatsu T, Chinen H, Kamada N, Imai T, Goto H, Hibi T (2007) Exclusive increaseof CX3CR1+CD28SCD4+ T cells in inflammatory bowel disease and their recruitment as intraepithelial lymphocytes. Inflamm Bowel Dis 13:837-846.

23. Liuzzo G, Biasucci LM, Trotta G, Brugaletta S, Pinnelli M, Digianuario G, Rizzello V, Rebuzzi AG, Rumi C, Maseri A, Crea F (2007) Unusual CD4+CD28null T lymphocytes and recurrence of acute coronary events. J Am Coll Cardiol 50:14501458

24. Kaplan MJ, Lu Q, Wu A, Attwood J, Richardson B (2004) Demethylation of promoter regulatory elements contributes to perforin overexpression in CD4+ lupus T cells. $\mathrm{J}$ Immunol 172:3652-3661.

25. Blanco P, Pitard V, Viallard JF, Taupin JL, Pellegrin JL, Moreau JF (2005) Increase in activated CD8+ T lymphocytes expressing perforin and granzyme B correlates with disease activity in patients with systemic lupus erythematosus. Arthritis Rheum 52:201-211.

26. Tan EM, Cohen AS, Fries JF, Masi AT, McShane DJ, Rothfield NF, Schaller JG, Talal N, Winchester RJ. (1982) The 1982 revised criteria for the classification of systemic lupus erythematosus. Arthritis Rheum 25:1271-1277. 
27. Hochberg MC (1997) Updating the American College of Rheumatology revised criteria for the classification of systemic lupus erythematosus. Arthritis Rheum 40:1725.

28. Bombardier C, Gladman DD, Urowitz MB, Caron D, Chang CH. (1992) Derivation of the SLEDAI. A disease activity index for lupus patients. The Committee on Prognosis Studies in SLE. Arthritis Rheum 35:630-640.

29. Chomczynski P, Sacchi N (1987) Single-step method of RNA isolation by acid guanidinium thiocyanate-phenol-chloroform extraction. Anal Biochem 162:156-159.

30. Podack ER, Lowrey DM, Lichtenheld M, Olsen KJ, Aebischer T, Binder D, Rupp F, Hengartner H (1988) Structure, function and expression of murine and human perforin 1 (P1). Immun. Rev. 103:203-211

31. Podack ER, Hengartner H, Lichtenheld MG (1991). A central role of perforin in cytolysis? Annu. Rev. Immunol 9:129-157

32. Hamann D, Baars PA, Rep MH, Hooibrink B, Kerkhof-Garde SR, Klein MR, van Lier RA (1997). Phenotypic and functional separation of memory and effector human $\mathrm{CD}^{+}$T cells. J. Exp. Med. 186:1407- 1418

33. Zheng CF, Ma LL, Jones GJ, Gill MJ, Krensky AM, Kubes P, Mody CH (2007) Cytotoxic CD4+ T cells use granulysin to kill Cryptococcus neoformans, and activation of this pathway is defective in HIV patients. Blood 109:2049-2057.

34. Saez-Borderias A, Guma M, Angulo A, Bellosillo B, Pende D, Lopez-Botet M (2006) Expression and function of NKG2D in CD4+ T cells specific for human cytomegalovirus. Eur J Immunol 36:3198-3206.

35. Haigh TA, Lin X, Jia H, Hui EP, Chan AT, Rickinson AB, Taylor GS (2008) EBV latent membrane proteins (LMPs) 1 and 2 as immunotherapeutic targets: LMP-specific CD4+ cytotoxic T cell recognition of EBV-transformed B cell lines. J Immunol 180:1643-1654.

36. Zhou W, Sharma M, Martinez J, Srivastava T, Diamond DJ, Knowles W, Lacey SF (2007) Functional characterization of BK virus specific CD4+ T cells with cytotoxic potential in seropositive adults. Viral Immunol 20:379-388.

37. Milikan JC, Kinchington PR, Baarsma GS, Kuijpers RW, Osterhaus AD, Verjans GM (2007) Identification of viral antigens recognized by ocular infiltrating $T$ cells from patients with varicella zoster virus-induced uveitis. Invest Ophthalmol Vis Sci 48:3689-3697.

38. Aslan N, Yurdaydin C, Wiegand J, Greten T, Ciner A, Meyer MF, Heiken H, Kuhlmann B, Kaiser T, Bozkaya H, Tillmann HL, Bozdayi AM, Manns MP, Wedemeyer H (2006) Cytotoxic CD4 T cells in viral hepatitis. J Viral Hepat 13:505514.

39. Silva CL, Lowrie DB (2000) Identification and characterization of murine cytotoxic $\mathrm{T}$ cells that kill Mycobacterium tuberculosis. Infect Immun 68:3269-3274.

40. Lu Q, Wu A, Ray D, Deng C, Attwood J, Hanash S, Pipkin M, Lichtenheld M, Richardson B (2003) DNA methylation and chromatin structure regulate T cell perforin gene expression. J Immunol. 170:5124-5132. 
41. Luo Y, Zhang X, Zhao M, Lu Q (2009) DNA demethylation of the perforin promoter in CD4(+) T cells from patients with subacute cutaneous lupus erythematosus. J Dermatol Sci doi:10.1016/j.jdermsci.2009.06.010

42. Appay V, Zaunders JJ, Papagno L, Sutton J, Jaramillo A, Waters A, Easterbrook P, Grey P, Smith D, McMichael AJ, Cooper DA, Rowland-Jones SL, Kelleher AD . (2002) Characterization of CD4(+) CTLs ex vivo. J Immunol. 168: 5954-5958.

43. De Jong R, Brouwer M, Hooibrink B, Van der Pouw-Kraan T, Miedema F, Van Lier RA (1992) The CD27- subset of peripheral blood memory CD4+ lymphocytes contains functionally differentiated $\mathrm{T}$ lymphocytes that develop by persistent antigenic stimulation in vivo. Eur J Immunol. 22: 993-999.

\section{FIGURE LEGENDS}

Fig.1. PRF1 transcript (A) and protein (B) levels and representative picture of western blot analysis $(\mathbf{C})$ in $\mathrm{CD}^{+}{ }^{+} \mathrm{T}$ cells from SLE patients and controls.

The $\mathrm{CD}^{+} \mathrm{T}$ cells were isolated from peripheral blood by positive biomagnetic separation technique, and were immediately used for RNA and protein isolation. Total RNA was reverse-transcribed, and cDNAs were investigated by RQ-PCR relative quantification analysis. The PRF1 mRNA levels were corrected to the amount of hMRLP19. The amounts of PRF1 mRNA were expressed as the natural logarithm of multiples of these cDNA copies in the calibrator. Proteins were separated using SDS-PAGE, transferred, and the membranes were immunoblotted respectively with primary anti-PRF1 Ab and secondary Ab. The membranes were reblotted with anti- $\beta$-actin HRP-conjugated Ab. The amount of western blotdetected PRF1 proteins was presented as the natural logarithm of PRF1-to $\beta$-actin band optical density ratio. $(\bigcirc)$ and $(\bullet)$ represent transcript levels in controls and SLE patients, respectively. *Median (range), ND-non detected. 
Fig. 2. The correlation between PRF1 transcript (A) and protein $(\mathbf{B})$ in $\mathrm{CD} 4^{+} \mathrm{T}$ cells and clinical activity of SLE scored in the SLEDAI scale.

The $\mathrm{CD}^{+}{ }^{+} \mathrm{T}$ cells were used for RNA and protein isolation. Total RNA was reversetranscribed into cDNAs and investigated by RQ-PCR relative quantification analysis. PRF1 mRNA levels were corrected to hMRLP19 levels. The quantities of PRF1 mRNA were expressed as the natural logarithm of multiples of these cDNA copies in the calibrator. The $\mathrm{CD}^{+} \mathrm{T}$ cell proteins were separated using SDS-PAGE, transferred, and the membranes were immunoblotted respectively with primary anti-PRF1 Ab and secondary Ab. The membranes were reblotted with anti- $\beta$-actin HRP-conjugated Ab. The amount of western blot-detected PRF1 was presented as the natural logarithm of PRF1-to $\beta$-actin band optical densities ratio. r-Spearman correlation coefficient. 
Table 1. Demographic, and disease activity of SLE patients

\begin{tabular}{|c|c|}
\hline Patients Number & 41 \\
\hline Sex (Female/Male) & $39 / 2$ \\
\hline Mean $( \pm$ SD) of age at diagnosis (years) & $36.2 \pm 13.3$ \\
\hline SLEDAI scores & Patients number \\
\hline $0-5$ & 13 \\
\hline $6-10$ & 11 \\
\hline $11-15$ & 4 \\
\hline$>16$ & 13 \\
\hline
\end{tabular}


Table 2. PRF1 transcript and protein levels in $\mathrm{CD} 4^{+} \mathrm{T}$ cells from SLE patients and controls

\begin{tabular}{|c|c|c|c|c|c|c|}
\hline & \multicolumn{2}{|c|}{ SLE } & \multicolumn{2}{|c|}{ Controls } & \multirow[b]{2}{*}{$\mathrm{p}$} & \\
\hline & Median (range) & Mean $( \pm \mathrm{SD})$ & Median (range) & Mean $( \pm \mathrm{SD})$ & & \\
\hline PRF1 & $\begin{array}{l}1.02(0.06-11.14)^{\mathrm{a}} \\
0.67(\mathrm{ND}-4.50)^{\mathrm{b}}\end{array}$ & $\begin{array}{l}1.66 \pm 2.23^{\mathrm{a}} \\
0.87 \pm 1.04^{\mathrm{b}}\end{array}$ & $\begin{array}{l}1.04(0.10-4.75)^{\mathrm{a}} \\
0.66(\mathrm{ND}-2.84)^{\mathrm{b}}\end{array}$ & $\begin{array}{l}1.34 \pm 1.24^{\mathrm{a}} \\
0.37 \pm 0.67^{\mathrm{b}}\end{array}$ & $\begin{array}{l}0.908^{\mathrm{a}} \\
0.013^{\mathrm{b}}\end{array}$ & $\begin{array}{l}{ }^{\mathrm{a}} \text { The target } \mathrm{mRNA} \text { levels } \\
\text { were corrected to the }\end{array}$ \\
\hline
\end{tabular}

cDNA and expressed as multiplicity of these

cDNA copies in calibrator. ${ }^{\mathrm{b}}$ The amount of western blot detected proteins was presented as the PRF1 to $\beta$-actin band optical density ratio. ${ }^{c}$ Mann-Whitney test, ND-non detected 


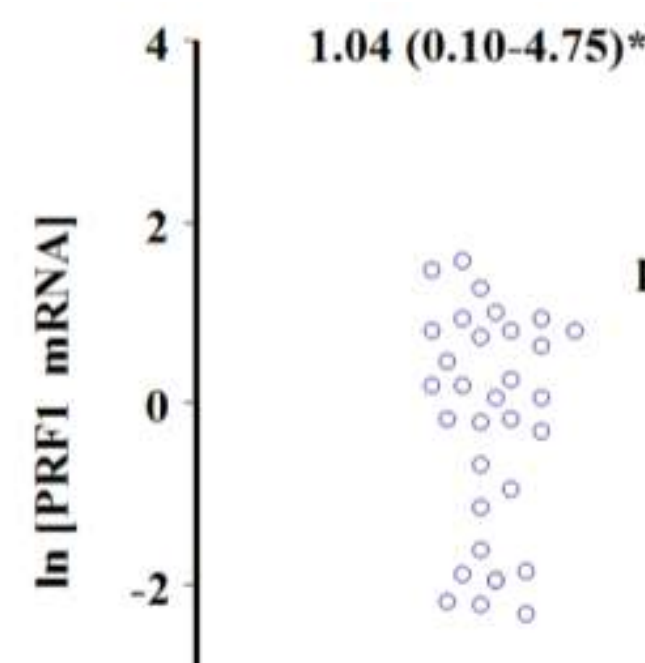

21

22

23

24

25

26

27

28

29

30

31

32

33

34

35

36

37

38

39

40

41 
C

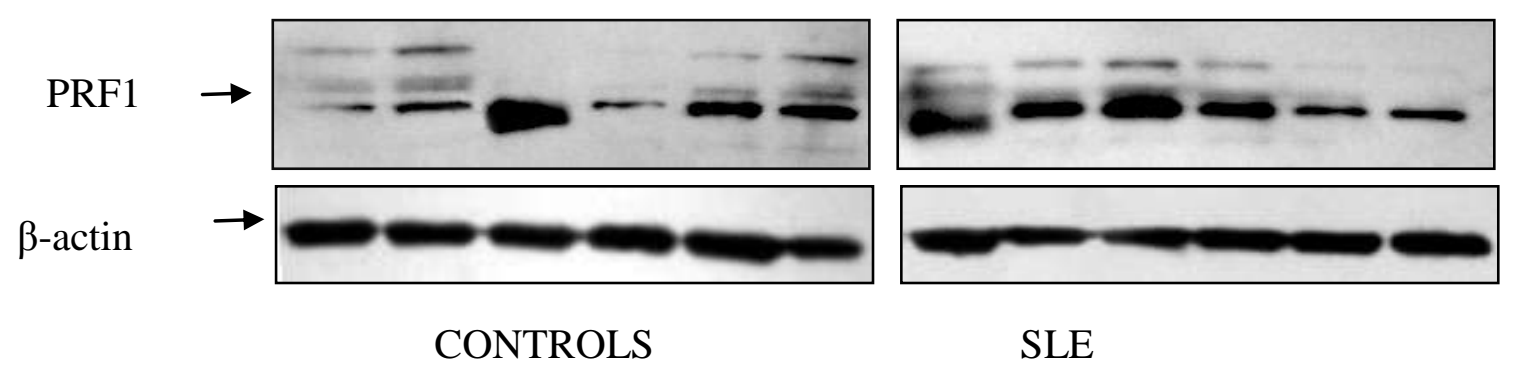

Fig. 1 


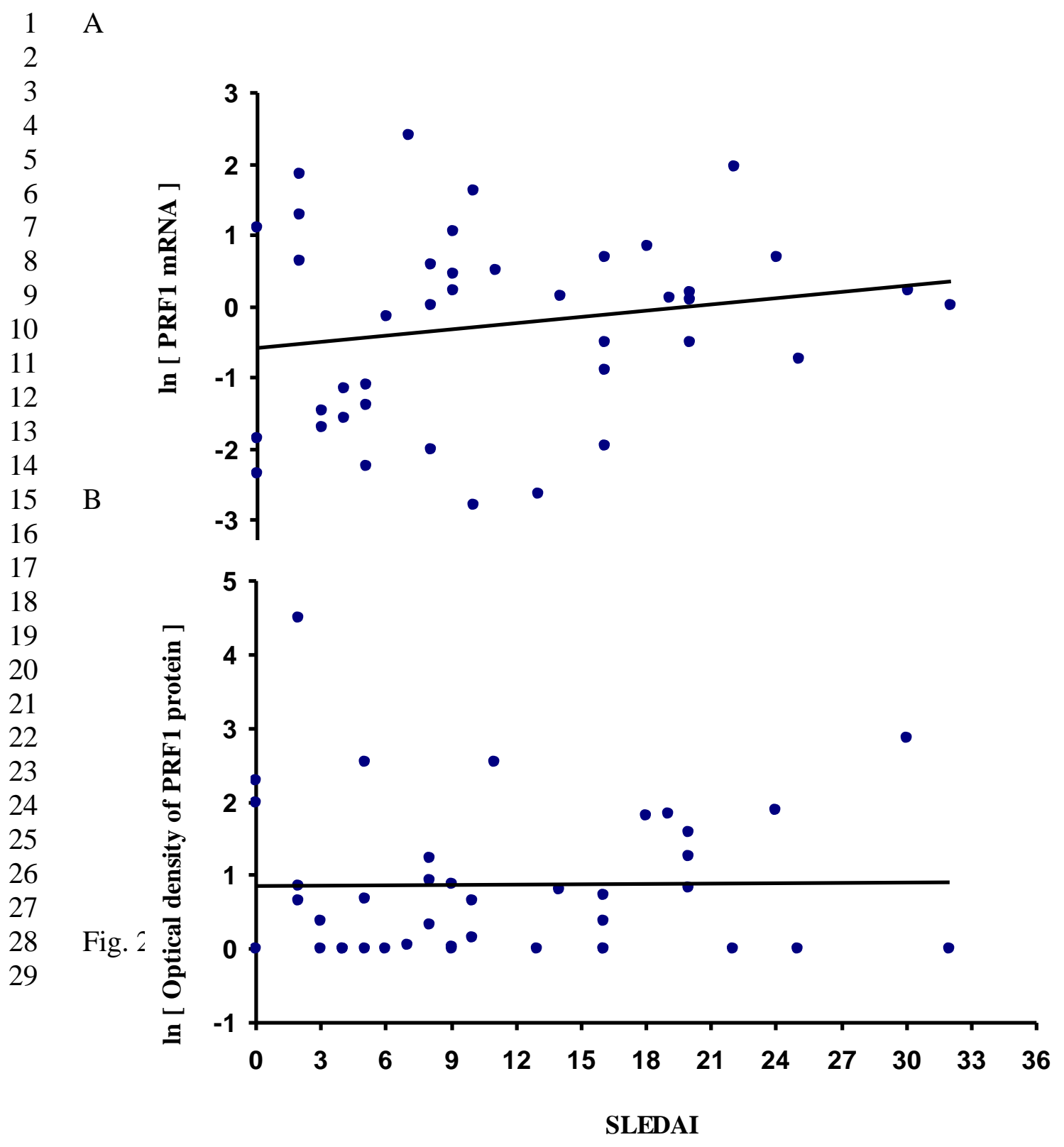

